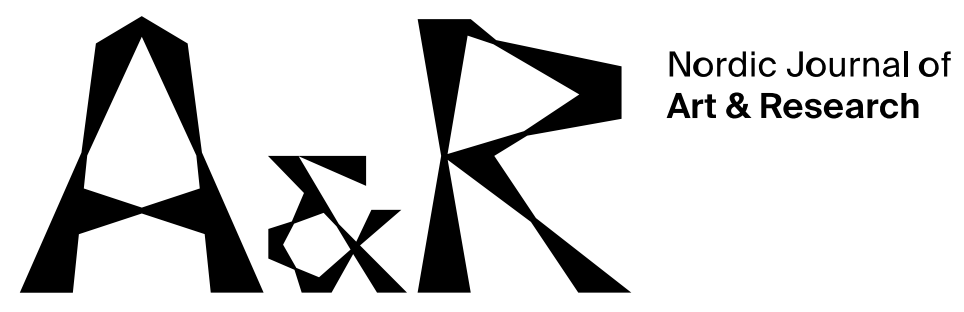

\title{
Wunderkammer - Ting- og kunnskapsorganisering i en aktivitetsbasert tidsalder
}

\author{
Vitenskapelig essay \\ Ingvard Bråten ${ }^{1}$ \\ Høgskulen på Vestlandet
}

\section{Sammendrag}

Dette essayet stiller spørsmål ved hvordan vi organiserer ting og kunnskaper. Inngangen er fortidens wunderkamre, spesifisert gjennom en bok av Samuel Quiccheberg fra 1565, samt bruken av et cellekontor i dag. Quicchebergs bok er beskrevet som den første avhandling som ser på hvordan en skal organisere samlinger. Cellekontoret har også sine ting og sin organisering, og dets subversive bruk er aktuell på grunn av vår tids debatter rundt kontorlandskap og aktivitetsbaserte arbeidsplasser. Essayet er satt sammen av flere mindre tekster med ulike språkdrakt. Her gis ingen svar på formulerte problemstillinger, men essayets søkende form er brukt som en metode for å se etter utenkte sammenhenger.

Nøkkelord: Kunnskap, ting, organisering, kunst og håndverk, wunderkammer, cellekontor, arbeidsplass

\footnotetext{
${ }^{1}$ Høgskolelektor ved Høgskulen på Vestlandet, Fakultet for lærarutdanning, kultur og idrett. Ingvard.braten@hvl.no
} 
Ingvard Bråten. Wunderkammer - Ting- og kunnskapsorganisering i en aktivitetsbasert tidsalder

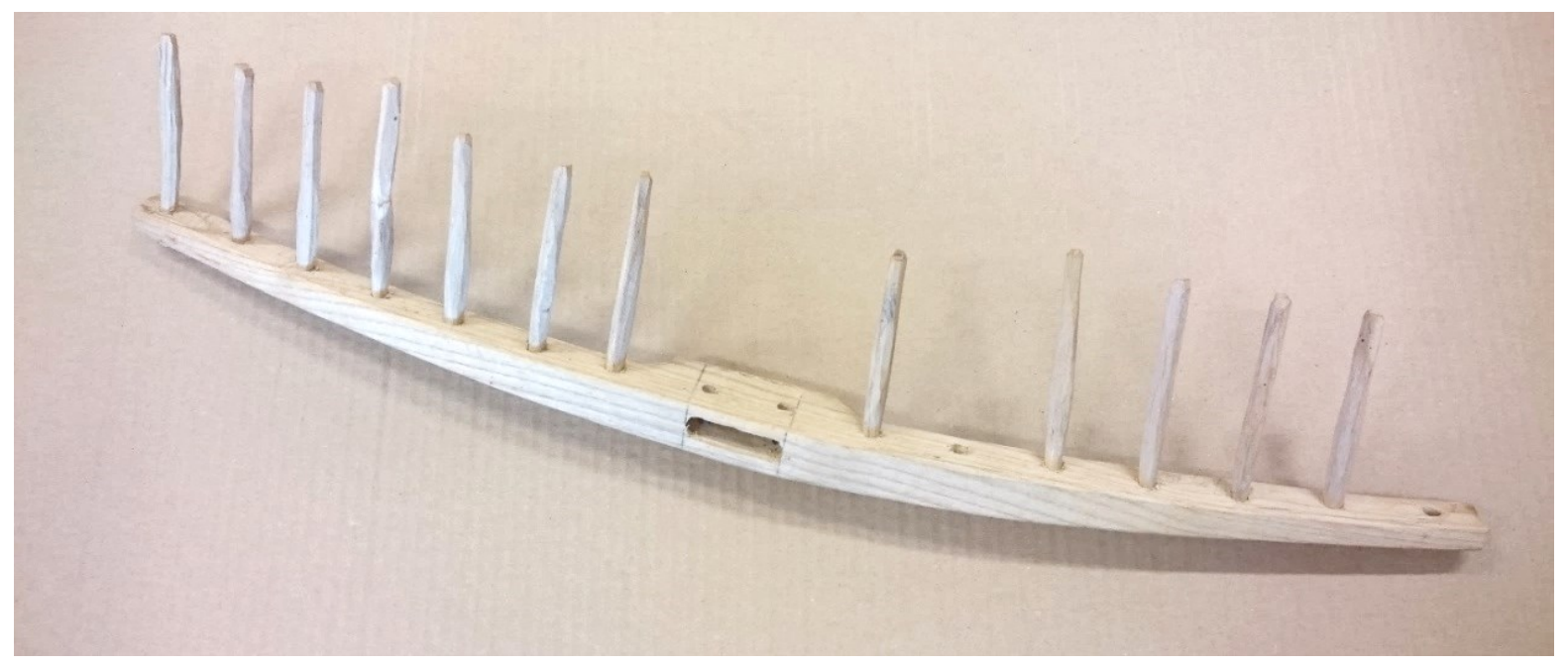

Figur 1. «Hode». Rivehode i ask fra Ulvik i Hardanger. Foto: Ingvard Bråten.

\section{Kunnskap}

En gammel trerive, skaft av gran eller furu, hode av ask eller eik, gjerne med tinder av hegg. Emne og treslag er valgt for sine egenskaper. Hodet må ikke være for tynt, da sprekker det, ikke for tykt, da blir riven tung å arbeide med.

Vår tid kjennetegnes av at andre kulturer og deres objekter er kommet nærmere, mens vår egen nære historie er fjernere. Det internasjonale erstatter det lokale, og redskap benyttet i generasjoner har snikende forsvunnet. I vår tid, som jeg drister å kalle den aktivitetsbaserte tidsalder, kan stadig mer av livet skje uavhengig av geografiske steder og fysiske møter mellom mennesker eller ting. Tjenester og kunnskap kan hentes ut, strømmes og aktiveres når vi ønsker. Tiden har en hang til å gjøre det hverdagslige kuriøst - til rariteter. Tiden gjør det funksjonelle ubrukelig. Tiden rører opp allmennkunnskapen, bytter den ut, utvider, justerer og visker vekk (Csikszentmihalyi \& Rochberg-Halton, 1981, s. 46; Thompson, 1979/2017). ${ }^{2}$

Mange steder kan en finne rivehoder lagd av bjørk. Bjørk er tilgjengelig i hele landet. En må passe litt bedre på når rivehodet er av bjørk. Bjørka tåler ikke fuktighet så godt. Da er det viktig å sette fra seg riva med hodet opp. En gang i tiden var ikke

2 Csikszentmihalyi \& Rochberg-Haltons «The meaning of things» baserer seg på studier av hva folks følelser for ulike gjenstander i hjemmet. Michael Thompson skrev i 1979 sin «Rubbish theory». Her gjør han analyser av hvordan objekter beveger seg mellom å være flyktige og varige, forkastet eller verdsatt. Boken kom i 2017 ut i ny utvidet utgave. 
Ingvard Bråten. Wunderkammer - Ting- og kunnskapsorganisering i en aktivitetsbasert tidsalder

dette nødvendig å si. Noen ting bare er slik, men kanskje finnes det kunnskap vi ikke trenger lenger.

\section{Undre}

Wunderkammer var de moderne museenes forgjenger. Dette var universalsamlinger en særlig kunne finne i de øvre lag av samfunnet på 15-, 16- og 1700-tallet. Her var kunst, bøker, måleinstrumenter, utstoppede dyr, redskaper og mye annet. Tingene lå på bord, stod på hyller, hang på veggene og i taket. Wunderkammer var maksimalisme. Å ha et rikholdig wunderkammer var et statussymbol (Meadows, 2001). Raritetskammer blir det oversatt til på norsk, cabinet of curiosities på engelsk. Samuel Quiccheberg (1519-1567) var en belgisk fysiker og vitenskapsmann. I 1565 kom hans bok Inscriptiones ut. Her beskriver Quiccheberg hvordan en burde samle og organisere en slik universalsamling av gjenstander. Den fulle tittelen på boken hans sier mye:

Inscriptiones or Titles of the most ample Theater That Houses Exemplary Objects and Exceptional Images of the Entire World, So that One Could Also Rightly Call It a: Repository of artificial and marvelous things, and of every rare treasure, precious object, construction, and picture. It is recommended that these things be brought together here in the theater so that by their frequent viewing and handling one might quickly, easily, and confidently be able to acquire a unique knowledge and admirable understanding of things. Authored by Samuel (sic). (Quiccheberg, $1565 / 2013$, s. 61$)^{3}$

\section{Ting}

Jeg har vært en samler hele livet. Som barn fylte jeg rommet mitt med ting. Her hadde jeg alt og ingenting. Her var steiner, fjær, maskindeler og reisesykeposer. Jeg hadde minst 20 slike poser - hvite med blå NSB-logo. Rommet mitt var tingenes asyl, her var de trygge. I voksen alder har jeg fått et nytt rom - cellekontoret. Nå er det her jeg samler det som ikke finner plass andre steder: Ting som er vakre eller stygge, men aller helst begge deler samtidig. Ting for handling eller tanke (Csikszentmihalyi

\footnotetext{
${ }^{3}$ Jeg har brukt en engelsk oversettelse av Samuel Quicchebergs avhandling. Boken er oversatt fra latin av Bruce Robertson og Mark A. Meadow. De to har skrevet henholdsvis forord og introduksjon til oversettelsen av Quiccheberg sin tekst.
} 
Ingvard Bråten. Wunderkammer - Ting- og kunnskapsorganisering i en aktivitetsbasert tidsalder

\& Rochberg-Halton, 1981, s. 96). Ting med minner, funksjon eller potensiale. Ting som fortjener noe mer.

\section{Framtid}

Samuel Quiccheberg var en konservatorpioner. Han var en mann med framtidsplaner. Avhandlingen han skrev, er den første kjente publiserte tekst som behandler hvordan en skal organisere samlinger (Meadow, 2013, s. 1). Avhandlingen er kort, bare 65 sider, men han hadde mer han ville si. Flere steder skrev han at ulike temaer ville bli behandlet grundigere i neste utgave. Sannsynligvis skrev han dette for å sikre finansiering til videre arbeid, for store leserskarer kan han ikke ha regnet med. Det var ikke så mange som hadde sitt eget wunderkammer, og særlig ikke i på den størrelsen Quiccheberg beskrev. Ved siden av å peke fram mot det som skulle komme, hadde Quiccheberg et virkemiddel til i sin søken etter finansiering. Han var omstendelig med å rose hertug Albert den femte av Bayern og andre adelsfolk med egne samlinger. Den neste utgaven av Quicchebergs inskripsjoner ble imidlertid aldri realisert. Han døde allerede i 1567. Teksten hans fikk heller ikke stor betydning i samtiden (Meadow, 2013, s. 2). Så langt man vet, har det aldri vært noen samlinger som egentlig brukte hans systemer og inndelinger. Andre fant sine egne veier. Det hjelper ikke alltid å være først.

\section{Flis}

Har du noen gang sett ordentlig godt på flis? Da vet du at flis er ikke bare flis. Høvel på osp, kniv i rå selje, avretter på bjørk og motorsag i frukttre. Hvert treslag har sin egen farge, struktur, fasthet, lukt og smak. Hvert verktøy gir flisa forskjellige former. «Du må gjerne snu flisa. Ho er flis på andre sida og» skrev min far (Bråthen, 1978, s. 33). Han må ha tenkt på noe annet, for flis er ikke bare flis. Flis er utallige variasjoner og kombinasjoner. Du merker dette hvis du samler den sammen, legger den lagvis i en

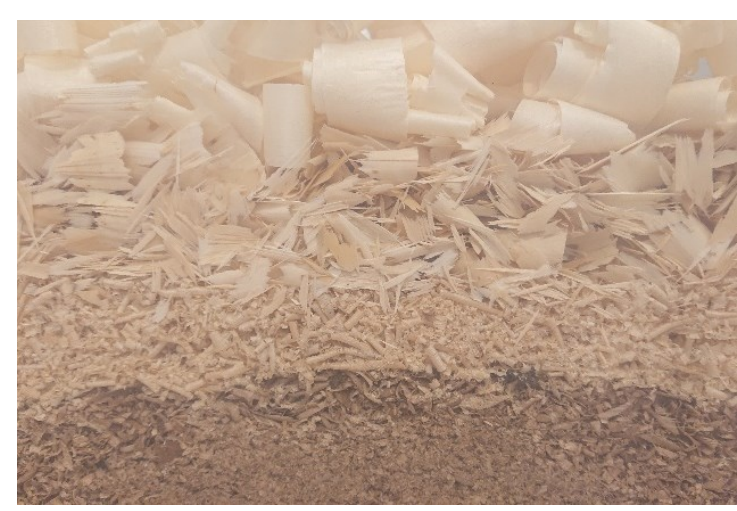

Figur 2. «Flis». Flis av ulike treslag, tilvirket av forskjellige verktøy og lagt lagvis i en transparent kasse. Foto: Ingvard Bråten. kasse og setter den på en hylle hvor du kan se den hver dag. 
Ingvard Bråten. Wunderkammer - Ting- og kunnskapsorganisering i en aktivitetsbasert tidsalder

\section{Teater}

Jeg arbeider med kunst og håndverk i lærerutdanning. På skolen min er det det store vinduer ved siden av kontordørene. Vinduene starter nede ved gulvet. De er 225 centimeter høye og 95 centimeter brede. Både lys, innsyn og utsyn er godt ivaretatt, men hva er her å se? Fra kontorene kan en i sidesynet se mennesker flagre forbi i gangen, og fra gangen kan en se de som bruker kontorene. De sitter foran en skjerm, bøyd over en bok, snakkende i telefonen eller i samtaler med besøkende. Det er verken passende eller interessant å stoppe for å se. I januar fikk jeg tildelt cellekontoret mitt. I februar begynte jeg å bygge reoler. Den første reolen var 224 centimeter høy og 94 centimeter bred, med seks åpne hyller. Jeg plasserte den foran vinduet. I hyllene satte jeg transparente kasser. I kassene la jeg det jeg samler og bruker. Jeg er fortsatt synlig fra gangen, men jeg liker å tenke at jeg nå blir sett gjennom materialer. Senere kom det nye reoler. Bak besøksstolen, under pulten, innenfor døren og over døren. Jeg lager regler for meg selv. Regel 1: Bygg i melaminplater og eik. Eik er hardt. Melamiplatene er et utakknemlig materiale å jobbe med, men de var her før jeg kom. De er den utdelte materialpaletten. Regel 2: Skru aldri noe fast i veggen. Det skal de ikke få på meg, at jeg løper rundt og lager hull i veggene. Regel 3: Ikke spør om lov. Sjansen for å treffe noen som vil sette til side systemet for å imøtekomme individuelle behov, er liten.

\section{Inndeling}

Wunderkamrene og Quicchebergs tinglige teater var arkivering, forskning, konversasjon og undervisning på samme sted. Det var samlinger som skulle bli brukt og endret, ikke betraktet etter konservatoriske løypekart (Meadow, 2002). Går du på et museum i dag, vil du gjerne finne at deler og rom er gitt til en kunstner, en epoke, stoler, en sølvskatt, raske biler eller kinesiske smykker. Her finnes en ide om at museet er for alltid. Gjenstandene som er kommet inn, skal aldri skal ut igjen (Lubar, Rieppel, Daly \& Duffy, 2017). ${ }^{4}$ Hva skjer hvis en stokker kortene og deler dem på nytt? - Rot? - Utvilsomt. - Muligheter? - Kanskje. Der det finnes ting, kan en også finne sammenhenger og lage inndelinger. Måten dette blir gjort på, får konsekvenser for hva en ser. Dette gjelder ikke bare for ting. Det gjelder for: temaer, lover, fagområder og mennesker. Inndelinger preger både utdanninger, forsking og institusjoner. Når inndelingene og sammenhengene er satt, får de ringvirkninger.

\footnotetext{
4 Professor i kunsthistorie Steven Lubar har gjennom mange arbeider forsøkt å vise hvordan museumsvesenet har endret seg gjennom historien. Han har sett på hvorfor man samler og hvordan hva man samler forandrer seg.
} 
Ingvard Bråten. Wunderkammer - Ting- og kunnskapsorganisering i en aktivitetsbasert tidsalder

Fagområder blir koblet sammen til fordel for andre: kunstfag for seg, realfag for seg, språkfag for seg. Men hva er et kunstfag og hva er det ikke? Jobber ikke alle fag med språk? Påvirker ikke naturens lover all menneskelig virksomhet og forståelse? På navneskiltet utenfor cellekontoret mitt står det institutt for kunstfag. I rommet ved siden av ligger det et lite lager. Her er det utstoppede dyr og skjeletter, men til den døren må man ha et annet nøkkelkort: Feil fag, feil institutt. I Quicchebergs teater hadde gjerne ikke veggen mellom rommene vært der i det hele. Vi mennesker trenger våre systemer, men når noe blir valgt, blir noe annet valgt bort. Er dette permanent? Hva skal til for at en inndeling eller en tenkemåte blir erstattet av en annen?

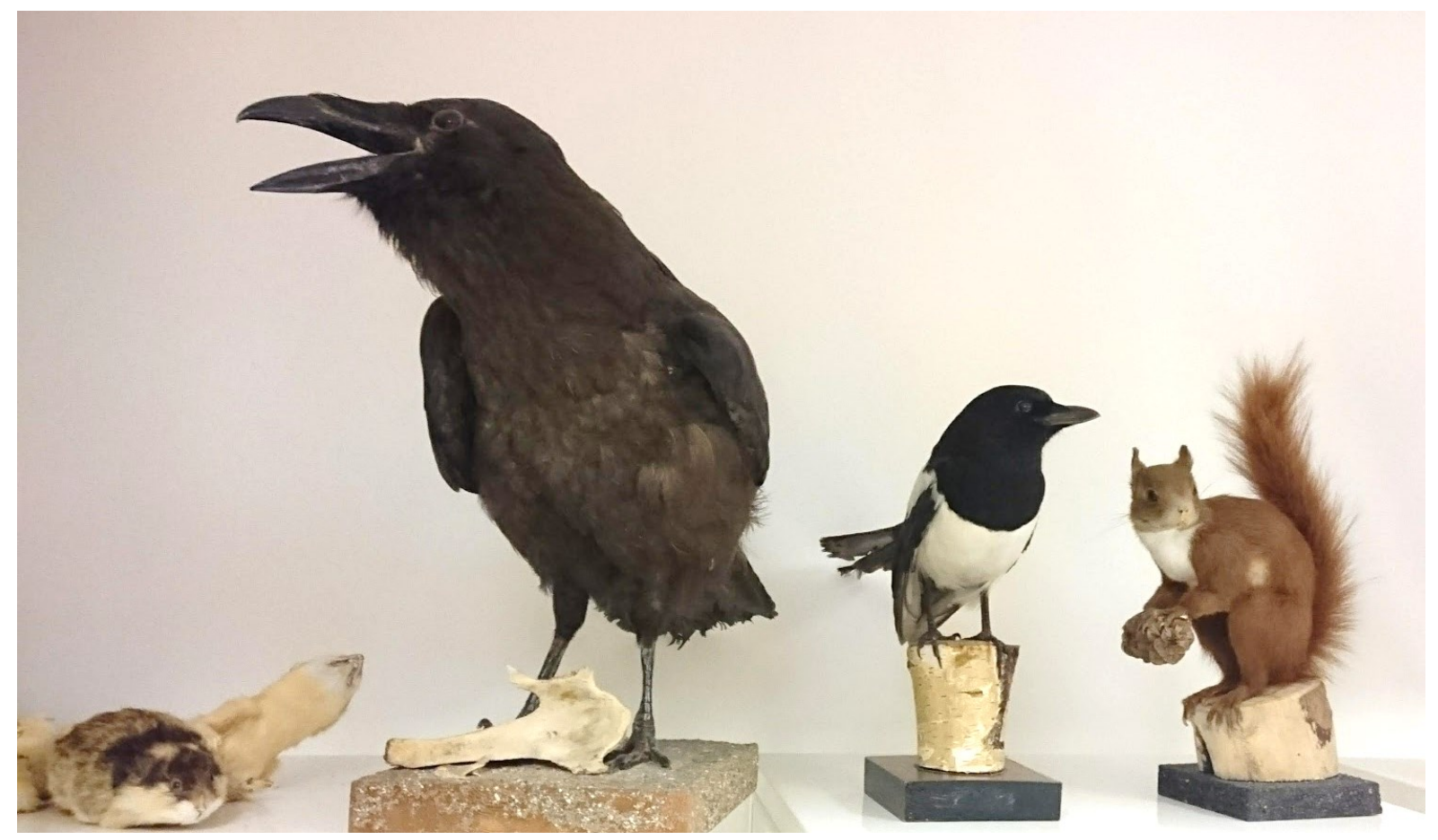

Figur 3. «Rommet ved siden av, nært men fjernt». Utstoppede dyr fra naturfagavdelingens lager på Høgskulen på Vestlandet. Foto: Ingvard Bråten.

Michel Foucault skriver om hvordan tingene setter spørsmålstegn ved enhver bås de blir satt i. Forordet til «Tingenes orden» begynner han slik: «Denne boken tar utgangspunkt i en tekst av Borges, i den latter som ved lesingen av den ryster alt det tanken er fortrolig med (...) en latter som rokker ved alle de velordnede overflater og inndelinger som for oss bringer orden og fornuft (...)» (Focault, 1966/1999, s. 7). Teksten til Jorge Luis Borges (1952/2010), som Foucault henviser til, omtaler et kinesisk leksikon som angivelig delte dyr inn i følgende kategorier: 
Ingvard Bråten. Wunderkammer - Ting- og kunnskapsorganisering i en aktivitetsbasert tidsalder

a) dyr som tilhører keiseren, b) balsamerte dyr, c) tamme dyr, d) pattegriser, e) sirener, f) fabeldyr, g) løshunder, h) de dyr som inneholdes i herværende klassifikasjon, i) som løper rundt som gale, j) som er utallige, k) som tegnes med en svært fin pensel av kamelhår, I) etcetera, $\mathrm{m}$ ) som nettopp har knust vannkrukken, n) som på lang avstand ser ut som fluer. (Borges, 1952/2010, s. 172)

Latteren over denne underfundige inndelingen, sier Foucault, påfølges av et ubehag. I kjølvannet av latteren fødes en fornemmelse av at det finnes systemer som er mer vilkårlige og umulige enn den som Borges gjengir, men som like fullt er systemer som styrer våre liv (Focault, 1966/1999, s. 10). Hva som er sant i en gitt tid vil ifølge Foucault, ikke være resultatet av en lineær historie om framskritt, tvert imot inneholder den mange fundamentale brudd som ikke kan spores tilbake til forrige epokes oppdagelser. «Åpenbart», sier Borges, «finnes det ikke noen inndeling av universet som ikke er vilkårlig og uviss. Grunnen er svært enkel: Vi vet ikke hva universet er for noe» (Borges, 1952/2010, s. 172). Hva vil så historien si om vår tids premisser for å organisere våre ting og vår kunnskap, våre museer eller arbeidsplasser? Vil våre valg framstå som rasjonelle for ettertiden? Og kanskje enda viktigere for oss som lever i dag: Hvilke ideologier, kunnskapsinnsamling eller tekniske nyvinninger tilsier at de endringene vi gjør innebærer framskritt?

Wunderkamrene hadde sine inndelinger. Dette var jo på mange måter Quicchebergs prosjekt, men om en noen gang skulle råke på «tamme dyr», «fabeldyr» og «dyr som på avstand ser ut som fluer» på samme sted, så måtte det vært her. For som Borges sier, så kan ikke vi mennesker oppgi våre forsøk på å utarbeide mønstre, uansett hvor provisoriske de måtte være (Borges, 1952/2010, s. 173). Viktigere enn inndelingene i et wunderkammer var likevel de åpne skottene mellom objekter og fagområder. Gjenstandene var der for å bli koblet opp mot hverandre, studert og brukt (Meadow, 2002). Tingene skulle stimulere til samtaler og kunnskapsutvikling. Samlingene ble sett i relasjon til andre rom i huset, slik som verksteder, bibliotek og kjøkken (Meadow, 2013, s. 26). Det moderne museumsvesenet, som særlig fant sin form ut over 1800 tallet, har en annen fortelling (Goga, 2007, s.14; Lubar, Rieppel, Daly \& Duffy, 2017). Her rendyrkes i hovedsak ett område, en epoke eller en hendelse.

I dag, i den aktivitetsbaserte tidsalder, rendyrkes også våre arbeidsplasser i en ny retning. Pultene ryddes for «free seating», og i de åpne kontorlandskapene måles det opp fire hyllemeter til hver ansatt. Her er ikke plass for skjønnheten i det tilfeldige 
Ingvard Bråten. Wunderkammer - Ting- og kunnskapsorganisering i en aktivitetsbasert tidsalder

møtet mellom en paraply og en symaskin på et disseksjonsbord (Comte de Lautréamont, 1870/1988, s. 159).

\section{Jeg har slikt å gjøre}

Det finnes mange samlere både i livet og i litteraturen. Askeladden roper: «Jeg fant jeg fant» til brødrene sine. Når de ber han kaste det han har funnet, repliserer han: «Jeg har slikt å gjøre, jeg har slikt å føre. Jeg fører vel den» (Prinsessen som ingen kunne målbinde, 1994). I eventyret får han bruk for det han har tatt med seg, det er slik han vinner prinsessa og kongeriket. En annen kjent tingsamler er Pippi Langstrømpe. Hun tar med seg Tommy og Anniken for å være tingletere. « - Hva er det, spurte Tommy. - En som leter opp ting, naturligvis! Hva skulle det ellers være, sa Pippi» (Lindgren, 1945/1988, s. 22). Pippi er tingleter med en overbevisning og begeistring som kanskje bare Askeladden kan konkurrere med. En mer stillfaren tilnærming enn Pippi og Askeladden får vi presentert av den russiske kunstneren llya Kabakov. Han har skapt karakteren Søppelmannen - mannen som aldri kastet noe. Vi får ikke møte eller se denne mannen, men Kabakov har skapt en installasjon som forestiller bostedet: En kommunal fellesleilighet i Sovjetunionen, som er fylt opp av det som har kommet i søppelmannens vei. Hver ting er sirlig merket med tidspunkt og en hendelse. Kabakov har også skrevet en kort novelle til installasjonen. I novellen reflekterer søppelmannen over forholdet mellom hva som er viktig og uviktig, og spør hvorfor et utvelgelsesprinsipp er bedre enn et annet:

En enkel følelse beretter om verdi, viktigheten av alle ting. (...) I våre sinn er alt like viktig og betydningsfullt. Alle begivenheter i hukommelsen er knyttet til hverandre. De danner kjeder og forbindelser i sinnet; minner som i sin konsekvens danner vårt liv, vår livshistorie. Å berøve oss for alt dette er det samme som å ta avskjed med hvem vi var i fortiden, og i en viss forstand så opphører vi da å eksistere. (...) Hvorfor skal sunn fornuft veie tyngre enn mine minner, sterkere enn alle de øyeblikkene i livet mitt som er knyttet til de papirbitene som nå virker rare og meningsløse? (Kabakov, 1996, s. 62)

En skulle nesten tro deLillos hadde sett Kabakovs installasjon når de synger: «Jeg tør ikke kaste noe, for jeg vil ikke glemme hvordan jeg fikk det. Hva er vitsen med å oppleve hvis jeg bare glemmer det» (deLillos, 1986, spor 11), men akkurat denne strofen blir sunget et par år før Kabakov presenterer søppelmannen for publikum for første gang. 
Ingvard Bråten. Wunderkammer - Ting- og kunnskapsorganisering i en aktivitetsbasert tidsalder

Pippi, Askeladden, søppelmannen og Lars Lillo-Stenbergs lyse stemme, hva er det de forteller oss? Trenger vi tingene for å huske? Kan et minne være fysisk, eller sagt på en annen måte, har vi minner som trenger fysiske representasjoner for å tre fram til bevisstheten? Litterære helter og antihelter som samler finnes det mange av, men de forenes helst i sitt utenforskap. De representerer en kontrast til samfunnsnormen. På samme måte som tingene de samler, passer de strengt tatt ikke inn. Når får så en samling verdi for andre enn den som har samlet? Kabakov hevder at alt hviler på historier, men at historiene først blir interessante når de fortelles sammen med de fysiske objektene. Det er ikke, sier han, interessant å høre om en tom sigarettpakke som ikke ble kastet, heller ikke å se et bilde av den. En må ha den tomme pakken (Kabakov, 1996, s. 30). For Kabakov er det historien som er verdifull, ikke tingen, men på samme måte som tingen trenger historien for å få verdi, får historien sin kraft gjennom tingen.

\section{Tapt og funnet}

På cellekontoret er det en brun, enkel eske som er merket «Funnet». Ved de fleste institusjoner er det en kasse, et skap eller et rom for det som er «tapt og funnet». Innholdet i denne esken er ikke tapt, men det er funnet. For må ikke noe være savnet for å bli kalt «tapt», eller holder det at eieren har mistet det uten å være klar over det? Kastet - mistet - savnet - tapt. Funnet - stjålet - flyttet - arkivert. Hvor går grensene? I esken på cellekontoret er det stive ark, på hvert ark er det festet noe. Under står det hva det er, hvor og når det ble funnet. Jeg er en Kabakovsk søppelmann i fjærvektklassen. Dette begynte med syv steiner: Jeg sitter ved skrivebordet. Jeg har tatt av meg skoene. Jeg utsetter noe jeg ikke har lyst til. Jeg kikker under skoene og ser det sitter steiner fast i sålen. Jeg pirker dem ut med en kniv og legger dem på pulten. Jeg flytter på dem og lager formasjoner. Jeg liker en bue jeg har formet, og tenker jeg vil ha den. Jeg limer steinene på et stivt ark og tar vare på arket. Senere fortsetter jeg med dette, når jeg finner noe som tiltaler meg, noe som får meg til å stoppe opp. De syv steinene var det første som ble arkivert på denne måten, det er mange år siden nå. Senere kom: «Vott, som lå på steinbenk», «Budsjett for Mathilde», «Revet takkekort» og mye annet. En gang fant jeg en lapp under isen på gårdsplassen hjemme. På den stod det: «Tenk om alt bare er en drøm». Sekundene før jeg forstod det var en lapp fra biblioteket med tittelen på en bok om surrealismen, var vidunderlige.

\section{I can't live with or without you}

Den samme egenskapen kan i ulike sammenhenger framstilles enten som en styrke eller som en svakhet. Fredelig - konfliktsky. Ettertenksom - introvert. Spontan - 
Ingvard Bråten. Wunderkammer - Ting- og kunnskapsorganisering i en aktivitetsbasert tidsalder

uvøren. Sparsommelig - gjerrig. Når egenskapen blir overdrevent tydelig, får det ofte karakter av å være en last, eller til og med en sykdom. Blant tingsamlere finner en dette i overdreven hamstring. Tenk om Askeladden aldri hadde kommet fram til kongsgården, rett og slett fordi sekken var blitt for tung uten at han klarer å forlate den. Når behovene en forestiller seg for framtiden er fullstendige urealistiske, kan hamstring bli en lidelse. Randy Frost og Gail Steketee har studert og jobbet med Hoarders (Frost \& Steketee, 2010). Hoarders er gjenstand for både studier, terapi og TV-underholdning. Frost og Steketee forteller om mange mennesker som har fått livene sine ødelagt fordi behovet for å samle tar fullstendig overhånd. En motsats til det å hamstre finner en i ryddefilosofier. Japanske Marie Kondo har blitt kalt ryddeguru og har skrevet flere bøker om hvordan en bør organisere hjemmene sine. I 2015 kåret magasinet Time henne til en av verdens 100 mest innflytelsesrike mennesker, og hun har fått en egen TV-serie på Netflix (KonMari, 2019). Er idealet i vår tid blitt å omgi seg med få, men utvalgte ting? Er samling blitt et forstadium til sykdom?

Wunderkamrene var personlige samlinger som for det meste var i hjemmet til eieren. Slik kan en kanskje si at Marie Kondo og Samuel Quiccheberg har noe til felles, siden begge er opptatt av hjem og organisering. Hva kunne de to snakket om? Jeg tror Kondo ville fortalt om hvordan hun allerede som barn fant stor glede i å rydde og organisere både hjemme og på skolen. At hun alltid var på jakt etter hva hun kunne kaste ut. Essensen, ville hun sagt, er å se på alle tingene en har, en kategori om gangen, og spørre om denne tingen «sparks joy» (KonMari, 2019). Hvis den ikke gjør det, kan du la den fare. Quiccheberg ville kanskje fortalt om hvordan han hele livet har vært fascinert av å samle. Hvordan ting gir forståelse og kunnskap når de blir satt sammen, og at en ikke kan vite hva en trenger fordi kunnskapens veier er snirklete og uforutsigbare. Kanskje de kunne skilles som venner ved å bli enige om at ting skal gi glede?

Sosialantropologen Mary Douglas har gitt oss et ganske enkelt begrepsapparat for hvordan en kan kategorisere ting. Ting er enten «a matter in place» eller «a matter out of place», sier hun (Douglas, 1966). Det er mennesker og situasjoner som definerer om en ting er på rett sted eller ikke. Slik sett finnes det ikke noe slikt som søppel. Den nederlandske designeren Jurgen Bey stilte seg selv spørsmålet om her fantes noe han ikke klarte å se noen nytte i (Studio Makkink \& Bey, 2019), eller sagt med Mary Douglas, noe som aldri er «a matter in place». Svaret han kom opp med, var «støv.» Dette resulterte i Vacuum Chair, en støvsugerpose formet som en stol. Når posen var full av støv, var stolen klar til å bli tatt i bruk. Fra «out of place» til «in place», men hvem definerer hva som hører til hvor? Hva hører til i wunderkammeret, 
Ingvard Bråten. Wunderkammer - Ting- og kunnskapsorganisering i en aktivitetsbasert tidsalder

på museet, i hjemmet, på cellekontoret? Anskaffelsen og vedlikeholdet av ting kan lett fylle opp et menneskeliv, inntil det ikke er tid igjen til å gjøre noe annet. Eller sagt i tråd med den svenske økonomen og statsmannen Stefan B. Linder: - Redskapene som i utgangspunktet skulle gjøre livet lettere, ender med å gjøre eieren til sin slave (Csikszentmihalyi \& Rochberg-Halton, 1981, s 53). Men mangelen på ting kan også stå i veien for å utøve et fag. «lkkje kom til meg med ein profesjonell ryddar!» skriver Astrid Hus i et leserinnlegg (Hus, 2018). Astrid har vært kunst og håndverkslærer hele livet og forteller at hennes skap og skuffer bugner av ting. Hun hevder at «Ein lærer meir av å sjå og kunne kjenne på, snu og vende på konkrete gjenstander enn å oppleve alt gjennom ein skjerm» (Hus, 2018).

Laurence Douny har i arven etter Mary Douglas, gjort en studie av avfallshåndtering blant Dogonfolket i Mali. Hun hevder at vi i Vesten ser på avfall i forhold til rom, mens Dogon-folket tenker i forhold til tid (Douny, 2007, s. 310). I stedet for å se på avfall som noe som må bort, ser Dogonfolket mer på avfall som en overgangsfase. Noe råtner og blir naturlig til jord, mens andre ting kan brukes til nye formål mer direkte. $\mathrm{Er}$ det slik vi samlere tenker? Med tiden vil det sikkert komme til nytte. Men når er det vi som eier tingene, og når er det tingene begynner å eie oss?

\section{Privat og profesjonell}

Cellekontoret er truet. Det er truet av aktivitetsbaserte arbeidsplasser, åpne kontorlandskap, «clean desk» og «free seating» (Skogland \& Skjæveland, 2016). Mari Skogland har forsket på aktivitetsbaserte arbeidsplasser og ser for seg at dette vil være den gjeldende normen om 10-20 år. «De færreste akademikere har strengt tatt behov for fysiske papirer, men papirarbeidet har blitt en vane», sier hun i et intervju (Bjørgan, 2018).

De åpne og fleksible løsningene, hvor fysiske rom er fristilt fra individet, er en annen måte å tenke på, en inndeling lagd fra et annet perspektiv. Et perspektiv der kunnskap er lagret på harddisker og i skyer og kan formidles gjennom nettforelesninger og «flipped classrooms». Fra dette perspektivet blir de fysiske gjenstandene forstyrrende vedheng, de lar seg ikke formatere, de passer ikke i skyen. Wunderkamrene ble på 1800 tallet erstattet av museer med klarere føringer. Skillet mellom hva som passet inn og hva som var uvedkomment, ble skarpere. «A matter in place» eller «a matter out of place» (Douglas, 1966) handler mer om hvem og når enn om hva.

Ved siden av verktøy, bøker, et rivehode og mye annet løsøre, er det 92 kasser og bokser på cellekontoret mitt, hver med en form for indre logikk, mer eller mindre 
Ingvard Bråten. Wunderkammer - Ting- og kunnskapsorganisering i en aktivitetsbasert tidsalder

elastisk. Til sammen har ikke tingene og innholdet i kassene og boksene noe annet til felles enn at det er relevant for meg personlig eller jobben min. - Det private og det profesjonelle, er det motsetninger eller to sider av samme sak? «Jo mer privat jeg tør være, jo mer allmenn er jeg. Da stemmer det med hvordan andre har det», sier tingkunstneren Jon Gundersen (Garvik, 2005). Men når er det plass for det personlige, og når står det i veien? I kunst, i undervisning, i forskning - i et essay? Wunderkamrene var personlige, men knapt private. De gjenspeilet interessene til den som hadde samlet dem. Et wunderkammer bar vitnesbyrd om eierens kunnskaper. Hva måtte han ikke vite han som hadde en slik bred og variert samling? Har en fattig samling av brukte ting, filler og flis den motsatte effekten?

\section{Tinder}

Riven har hull til 16 tinder, 12 av dem er på plass. Hver tind er 10 centimeter lang. Det vil si, den lengste er 101 millimeter, den korteste er 92. Alle er lagd ut fra en tanke om likhet, men ikke mer enn nødvendig. Riven fungerer med noe avvik, og ved behov kan tindene justeres senere. Ser en på dem enkeltvis, er de ikke lenger så like. De to midterste har en dobbel funksjon. Ved siden av å samle høy som de andre, så fester de også skaftet til hodet. Noen tinder er nesten helt rette, andre er litt bøyd. På hver tind er det fasetter etter kniven som har spikket dem til. De minner om Bård Breiviks søyler. Hver søyle bærer sin bør for fellesskapet, men hver for seg er de unike. Min mor har fortalt om kvelder i barndommen. De satt på kjøkkenet. Min mormor sydde, min morfar spikket rivetinder.

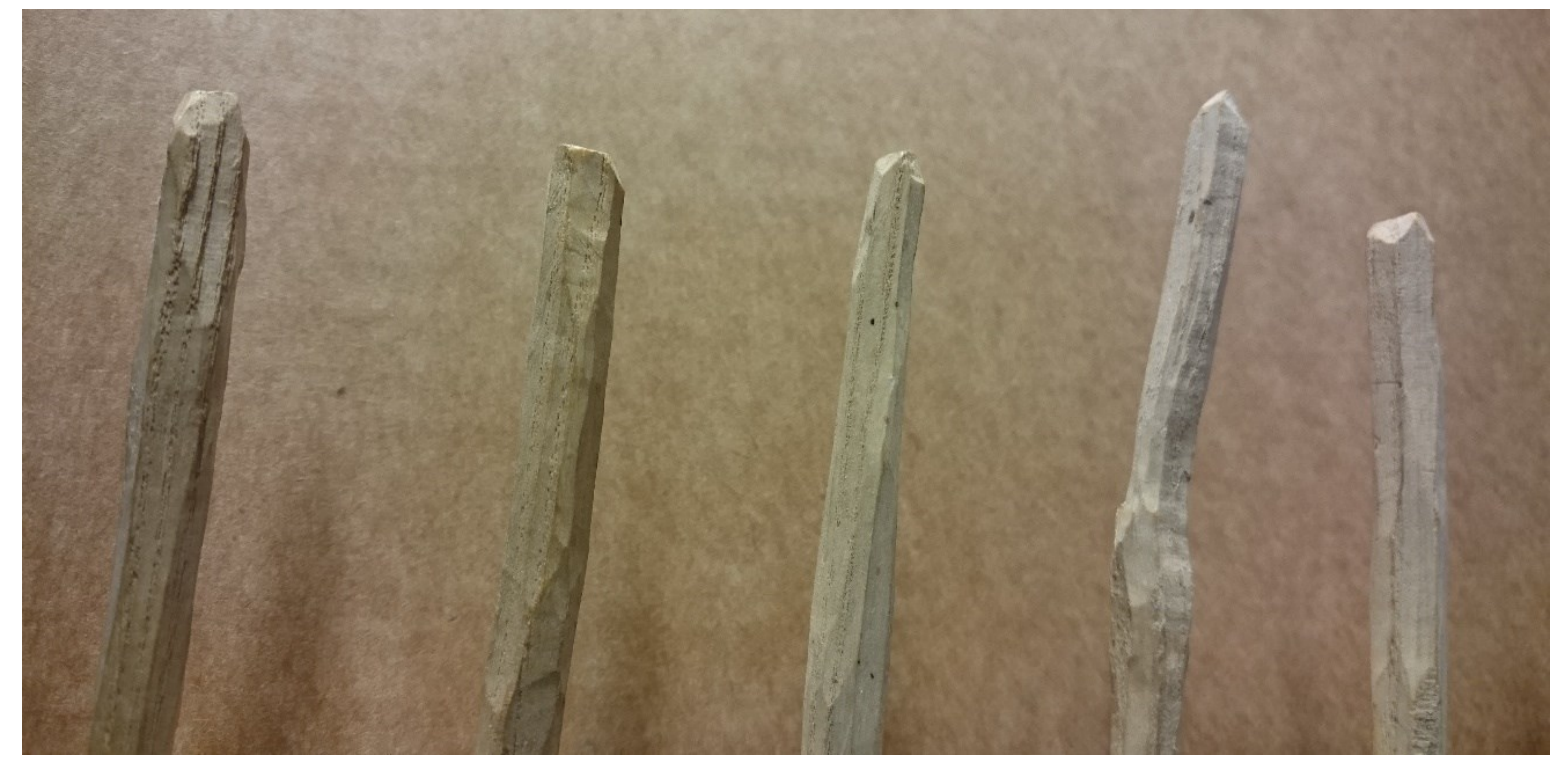

Figur 4. «Tinder». Nærbilde av rivetinder i ask. Foto: Ingvard Bråten. 
Ingvard Bråten. Wunderkammer - Ting- og kunnskapsorganisering i en aktivitetsbasert tidsalder

\section{Dele}

På Galtvort høyere skole for hekseri og trolldom, i syvende etasje, ligger nødvendighetsrommet (Rowling, 2001). Døren til rommet er skjult og viser seg først hvis en går forbi den tre ganger og tenker på hva en trenger. I sin opprinnelige form er rommet fylt fra gulv til tak av magiske og usannsynlige gjenstander, men transformer seg i størrelse og innhold ut fra behov. Det blir det det trenger å være for den som trenger det. - Magi? - Utvilsomt, men like fullt avhengig av at noen definerer et behov og ser etter muligheter. Cellekontoret mitt ligger i tredje etasje. Av og til stopper det noen utenfor vinduet, studenter, de ser i reolen som står foran vinduet, på leting etter noe, før de banker på og spør. Noen vet hva de trenger, andre har mer flytende behov. Med brikolørens (Lévi Strauss, 1972, s. 17) blikk undersøker de hyllene. Det er tilfredsstillende å være den som har, den som kan dele. Gleden med å samle går hånd i hånd med gleden av å se ting gå videre. «Når du har noe som er godt og brukbart, er det riktig å tilby det til den som på best måte kan dra nytte av det, og som kan være dets beskytter» (Quiccheberg i Quiccheberg, 1565/2013, s. 58). ${ }^{5}$ Dette skriver Leo Quiccheberg, Samuels bror, i et brev. Her tilbyr han Samuels inskripsjoner til keiser Maximilian den andre. Å dele med andre er ikke bare en uselvisk handling. Andres takknemlighet, blikk og aksept er drivkraften bak mange menneskelige handlinger. En kunstner «som skaper sin kunst for kjellerboden, er sjelden en lykkelig kunstner» sier Bjørn Hatterud (Hatterud, 2019, s. 153). En samler som aldri får aksept sin samlings verdi er heller ingen lykkelig samler.

\section{Strekmål}

Det går to riper på langs av rivehodet, en over og en under. Disse ble satt der for å vise hvor en skulle bore hull for tindene. Strekmål heter verktøyet som har lagd ripene. En gang hadde skolene klassesett av strekmål. I dag er de sjelden å finne i kunst og håndverkssalene, og det er langt mellom elever som vet hva det er. Kanskje finnes det kunnskap en ikke trenger lenger?

${ }^{5} \mathrm{Min}$ oversettelse fra engelsk. 
Ingvard Bråten. Wunderkammer - Ting- og kunnskapsorganisering i en aktivitetsbasert tidsalder

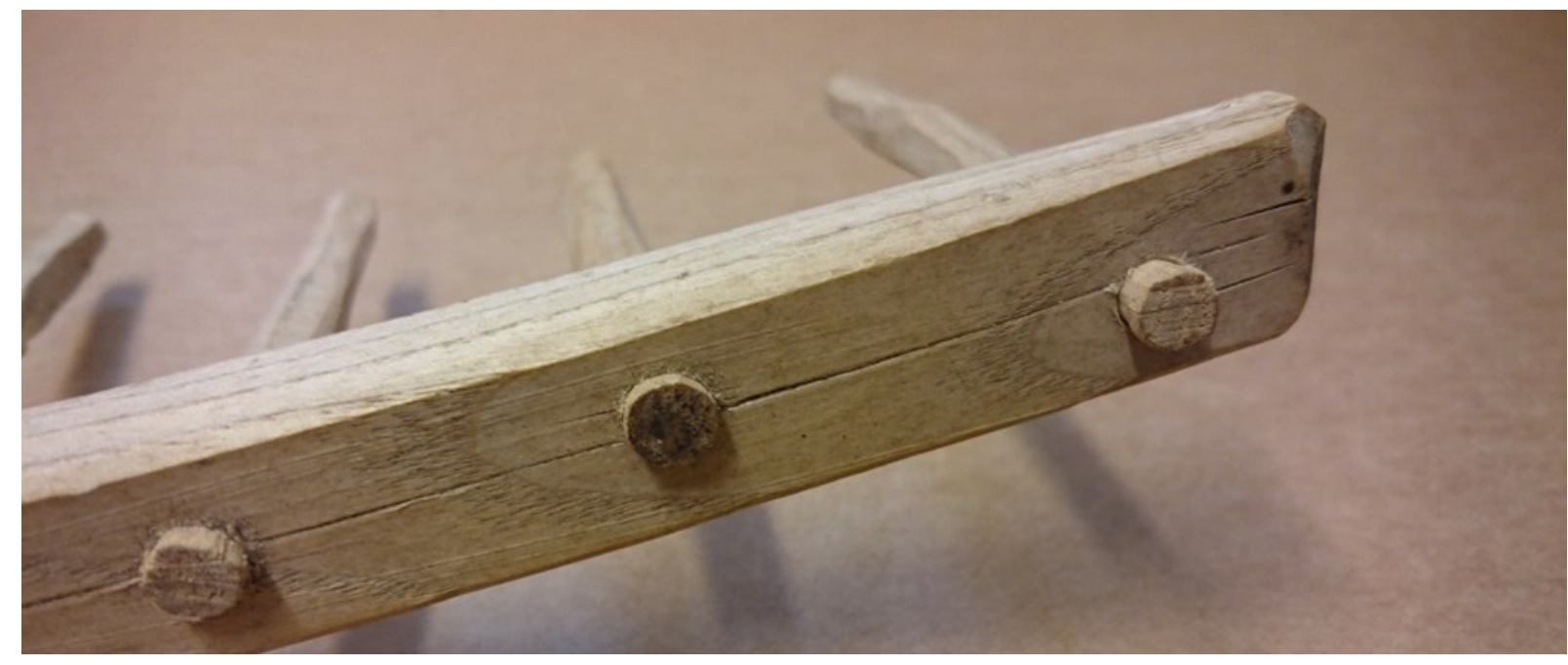

Figur 5. «Strek». Detalj fra rivehode med linje fra strekmål. Foto: Ingvard Bråten.

\section{Forfatterpresentasjon}

Ingvard Bråten arbeider som høgskolelektor ved Høgskulen på Vestlandet, fakultet for lærerutdanning, kultur og idrett, institutt for kunstfag. Her underviser han i forming/ kunst og håndverk i barnehage- og grunnskolelærerutdanningen. Tidligere har han arbeidet mange år som kunst og håndverkslærer i grunnskolen. Gjenbruk og tingenes muligheter er et gjengangertema i hans virke.

\section{Referanser}

Bjørgan, E.H. (2018, 14. juni). Fritt plassvalg fungerer bedre enn faste plasser.

Universitetsavisa. Hentet fra

https://www.universitetsavisa.no/campus/2018/06/14/Fritt-plassvalg-fungererbedre-enn-faste-plasser-18364735.ece

Borges, J.L. (2010). John Wilkins' analytiske språk. Oversatt av Gisle Selnes. Agora

- Journal for metafysisk spekulasjon, 28(4), 170-173. Hentet fra

https://www.idunn.no/file/ci/59687842/John Wilkins analytiske spraak.pdf

Bråthen, E. (1978). Tømmerstokktankar. Oslo: Gyldendal Norsk Forlag.

Csikszentmihalyi, M. \& Rochberg-Halton, E. (1981). The meaning of things: Domestic symbols and the self. Cambridge: Cambridge University Press.

https://doi.org/10.1017/CBO9781139167611

DeLillos. (1986). Suser avgårde [CD]. Oslo: Basic Music.

Douglas, M. (1966). Purity and Danger. London: Routledge.

Douny, L. (2007). The materiality of domestic waste: The recycled cosmology of the

Dogon of Mali. Journal of material culture, 12(3), 309-331.

https://doi.org/10.1177/1359183507081897 
Ingvard Bråten. Wunderkammer - Ting- og kunnskapsorganisering i en aktivitetsbasert tidsalder

Focault, M. (1996). Tingenes orden: En arkeologisk undersøkelse av vitenskapene om mennesket. Oslo: Aventura Forlag.

Frost, R. \& Steketee, G. (2010). Stuff: Compulsive hoarding and the meaning of things. New York: Houghton Mifflin Harcourt.

Garvik, B. (2005, 3. februar). Når alle ting blir en helt annen ting. Bergens Tidende, s. 42.

Goga, N. (2007). Kunnskap og kuriosa: Merkverdige lesninger av tre norske tekstmontasjer for barn og unge (Doktorgradsavhandling), Universitetet i Bergen. Hentet fra

http://dspace.uib.no/bitstream/handle/1956/3140/Dr.Thesis Nina Goga.pdf?s equence=2\&isAllowed $=y$

Hatterud, B. (2019). Det som tiden ikke tar. Billedkunst 40 (1), 151-155.

Hus, A. (2018, 4. april). Ikkje kom til meg med ein profesjonell ryddar [Leserinnlegg]. Bergens Tidende. Hentet 21. mai 2019 fra https://www.bt.no/btmeninger/debatt/i/l1bzjo/ikkje-kom-til-meg-med-einprofesjonell-ryddar

Kabakov, I. (1996). Søppelmannen. Oslo: Museet for samtidskunst.

KonMari. (2019). She started it. Hentet 20. mai 2019 fra https://konmari.com/pages/about

Lévi-Strauss, C. (1972). The savage mind. London: Weidenfeld and Nicolson.

Comte de Lautréamont. (1988). Maldorors sanger: Gjendiktet av Annie Riis. Oslo: Gyldendal Norsk Forlag

Lindgren, A. (1988). Her kommer Pippi. Oslo: Bokklubbens Barn.

Lubar, S., Rieppel, L., Daly, A. \& Duffy, K. (2017). Lost Museums. Museum History Journal, 10(1), 1-14, https://doi.org/10.1080/19369816.2016.1259330

Meadow, M. A. (2001). Merchants and Marvels: Hans Jacob Fugger and the Origins of the Wunderkammer I P. Smith \& P. Findlen (Red.), Merchants and Marvels: Commerce, Science and Art in Early Modern Europe (s. 182-200). New York: Routledge.

Meadow, M. A. (2013). Introduction. I S. Quiccheberg, S. The first treatise on museums: Samuel Quicchebergs's inscriptiones 1565. Overs. B. Robertson \& M. A. Meadow (s. 1-41). Los Angeles: Getty Publications.

Prinsessen som ingen kunne målbinde (1994). I: K. Nedrelid (red.), Asbjørnsen og Moe's norske folkeeventyr. Hentet 8. mai, 2019 fra http://runeberg.org/folkeven/048.html

Quiccheberg, S. (2013). The first treatise on museums: Samuel Quicchebergs's inscriptiones 1565 (B. Robertson \& M. A. Meadow, Overs.). Los Angeles: Getty Publications. 
Ingvard Bråten. Wunderkammer - Ting- og kunnskapsorganisering i en aktivitetsbasert tidsalder

Rowling, J.K. (2001). Harry Potter og ildbegeret. Oslo: Damm

Skogland, M. \& Skjæveland, O. (2016). Cellekontor, kontorlandskap eller free seating: Hva er best?

Arbeidsplassarkitektur i et endringsperspektiv. Arkitektur N, 98(6), 64-71. Hentet fra https://www.arkitektur-n.no/artikler/cellekontor-kontorlandskap

Studio Makkink \& Bey. (2019). 4030 Dust Furniture, 2004. Hentet 21. mai 2019 fra http://www.studiomakkinkbey.nl/list/products/4030 dust furniture/2114

Thompson, M. (2017). Rubbish Theory: The creation and destruction of value second edition. London: Pluto Press. https://doi.org/10.2307/j.ctt1rfsn94 